\title{
Comparative Study On The Endo-Parasitic Infestation In Clarias Gariepinus Collected From Earthen And Concrete Ponds In Makurdi, Benue State, Nigeria.
}

\author{
Omeji, S., S.G. Solomon And Uloko, C. \\ Department Of Fisheries And Aquaculture, University Of Agriculture, P.M.B. 2373, Makurdi, Benue State, \\ Nigeria.
}

\begin{abstract}
The study was conducted to collect and identify endoparasites of Clarias gariepinus from earthen and concrete ponds, Victory Fish Farm, Makurdi, and to determine the prevalence and intensity of infestation brought about by the endoparasites in the hosts. Of the eighty (80) Clarias gariepinus from earthen pond, 32 (40\%) were not infested while $48(60 \%)$ were infested and were observed to harbor a total of 62 endo-parasites belonging to two species of nematode (Eustrongylides and Camallanus), and two species of protozoa (Hexamita and Trypanosoma) while out of the 80 Clarias gariepinus from the concrete, it was observed that 64 (80\%) of the fish were not infested while 16 (20\%) were infested by endo-parasites and were observed to harbour a total of 24 endo-parasites belonging to two species of nematode (Eustrongylides and Camallanus) and one species of protozoa (Hexamita). It was observed that male fish from the earthen pond had more percentage parasitic infestation (64.29\%) than the female fish (57.69\%) while in the concrete pond, female fish had more percentage parasitic infestation (22.73\%) than the male (16.67\%). It was observed that bigger fishes of weight class between 750-849g were more infested than the smaller counterpart of less than (149g) from both ponds. In the earthen pond, the highest percentage intensity of infestation (0.83\%) was recorded in fish with the weight class between 750-849g while the lowest was recorded in fish with weight class between 250-349g. on the other hand, the highest percentage intensity of infestation (0.42\%) was recorded in fish with the weight class between 750 $849 \mathrm{~g}$ while the lowest was recorded in fish with weight class less than $149 \mathrm{~g}$.
\end{abstract}

Key words: Endoparasites, Clarias gariepinus, earthen pond, concrete pond.

\section{Introduction}

Fish has continued to be the most easily affordable source of animal protein to the average Nigerian family (Haruna, 2006). A break down showed, fish accounts for more than forty percent of the protein diet of two - third of the global population (Eyo (1992), FAO (1999)). Due to increase in human population, demand for fish as a source of protein is on the increase (Abolarin, 1996). In recent times, there has been a tremendous increase in the development of fish farming and culture due to increase need for animal protein. Nigeria has an estimated 12.5mha of freshwater surface area of lakes, reservoirs and ponds (Ibeun, 2006) which are capable of producing 521,000 metric tons of fish but have not succeeded in attaining fish food sufficiency (FAO, 1990).

Parasites of fish are a concern since they often produce a weakening of the host`s immune system thereby increasing their susceptibility to secondary infections, resulting in the nutritive devaluation of fish and subsequent economic losses (Onyedineke et al., 2010). Parasites also compete for food, thereby depriving fish of essential nutrients and inhibiting growth leading to morbidity and mortality with consequent economic losses (Khalil and Polling, 1997). Under intensive fish culture conditions, parasites tend to proliferate, because of compromised water quality (Paperna, 1991). In recent times, attention has shifted to fish parasites due to increased aquacultural practices. Information is available on parasites of cultured and wild fish (Chandra, 2006; Doreen et al., 2009; Martinez-Aquino and Anguilar-Anguilar, 2008; Shukerova et al., 2010; Omeji et al., 2011). Disease is an important factor militating against fish production. Many diseases are closely linked to environmental deterioration and stress, once the environment is disturbed, the organisms under such culture systems are stressed (SEAFDEC, 1999). In Nigeria the level of awareness of the impact of disease to aquaculture is lacking as revealed by numerous personal interactions and the report of Kolndadacha, et al, (2007). Parasitic diseases of fish are very common all over the world and are of particular importance in the tropics (Roberts and Janovy, 2000). Fish is the most parasitize of all vertebrate and the importance of parasitic infection on fish production has largely remained an issue of concern to fish farming industry. Some parasites have been discovered to have zoonotic potential in mammalian host including man thereby making them of public health importance. However, in instances where hosts are overcrowded such as in aquaria and fish farms, parasitic diseases can spread very rapidly causing gross mortalities (Paperna, 1996).

In fish farming or aquaculture, some parasites may be highly pathogenic and contribute to high fish mortalities and economic loss, while in natural systems they may threaten the abundance and diversity of 
indigenous fish species (Mashego, 2001). Clarias gariepinus is one of the most resistant and widely accepted and highly valued fish that could be cultivated in Nigeria, therefore the need for documented research on parasites which might constitute serious problems on this fish cannot be over emphasized Dankishiya and Zakari (2007). This paper aims at investigating the endoparasites of Clarias gareipinus from earthen and concrete ponds and to describe the incidence in relation to sex and size.

\section{Materials and Methods.}

Victory Fish Farm is located in Makurdi the capital of Benue state, Nigeria, longitude $7^{0} 43^{\prime} \mathrm{N}$ and latitude $8^{0} 32^{\prime}$ E. The town is divided into the North- and South- bank by the river Benue. River Benue which serves as a source of water supply to the farm exists year round though the water volume fluctuates with season. The river overflows its banks during the rainy season (May-October), but decrease drastically in volume leaving tiny island in the middle of the river during the dry season (November-April).

\section{Collection, Identification And Processing Of Fish Samples For Parasite Examination.}

A total of one hundred and sixty samples comprising of eighty (80) specimens of catfish, Clarias gariepinus each from the earthen and concrete ponds were collected from Victory Fish farm Makurdi, Benue State Nigeria. Each fish was assigned a reference number to ensure proper documentation of records and transported immediately alive to the laboratory at the National Veterinary Research Institute, Vom Jos Plateau State. The specimens were identified using the meristic features provided by Willoughby (1974). The sexes of the fish were determined after dissection (Martinez-Aquino et al., 2004). The total length and standard length of each fish were measured in centimeters $(\mathrm{cm})$ using a meter rule, while the weight was taken in grams using an electronic metler balance (Model AE 166). The total length, standard length and body weight were measured using standard procedure described by King (1996). The sex was determined by examination of genital pore and dissection to expose the gonads.

\section{Determination Of Endo-Parasite}

The fish were first immobilized to prevent it from struggling during dissection, and placed on a dissecting board. The body cavity was opened with the aid of a dissecting kit starting from the genital papillae down to the gill region. The intestine and the stomach of each of the fish were cut opened and contents squashed into the Petri-dish containing 0.9\% saline solution, Placed in a separate dish. Each drop of the residue was placed on the slide and viewed under x 10 and x 40 objective light microscope. The observed parasites were compared with the keys of fresh water fish parasite pictorial guide by Deborah et al, (2005). The parasites were counted and recorded.

Blood was collected from the caudal vein with a 23 gauge plastic syringe as described by Kori-Siapere and Ake (2005). A thin blood smear was made from the blood collected. The blood smears was allowed to air dry and fixed in absolute methanol. The smear was then examined by placing it in a $10 \mathrm{X} 40$ magnification of electronic microscope. The observed parasites were compared with the keys of fresh water fish parasite pictorial guide by Deborah et al, (2005). The parasites were counted and recorded.

\section{Sampling Area}




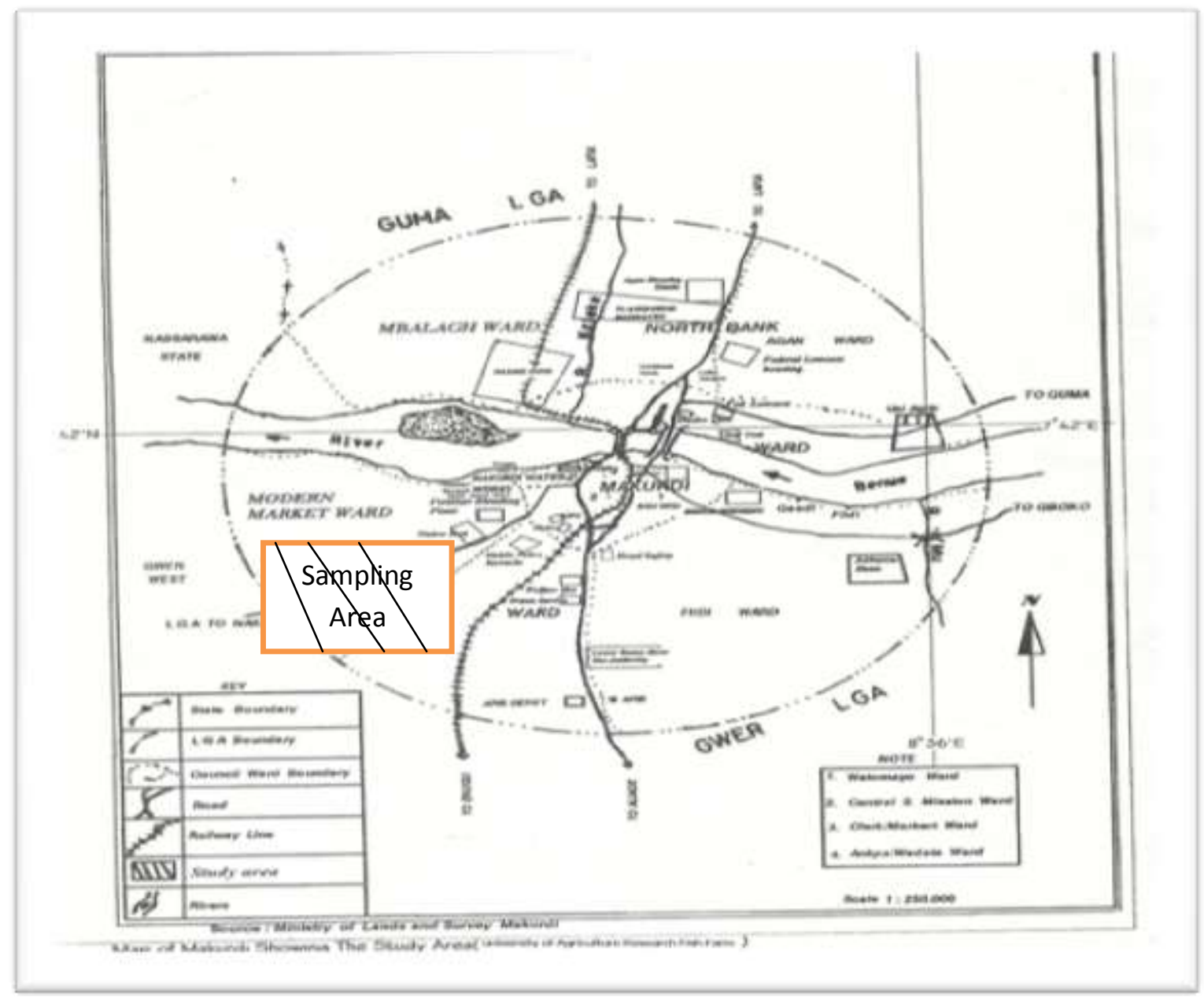

Fig. 1: Map of the study area.

III. Result

Of the eighty (80) Clarias gariepinus from earthen 32 (40\%) were not infested while 48 (60\%) were infested and were observed to harbor a total of 62 endo-parasites belonging to two species of nematode (Eustrongylides and Camallanus), and two species of protozoa (Hexamita and Trypanosoma) as shown in Table 1 while Table 2 shows results of the 80 Clarias gariepinus from the concrete ponds used for the study. It was observed that $64(80 \%)$ of the fish were not infested while $16(20 \%)$ were infested by endo-parasites and were observed to harbour a total of 24 endo-parasites belonging to two species of nematode (Eustrongylides and Camallanus) and one species of protozoa (Hexamita).

The occurrence of the endo-parasites in both sexes of the fish from both earthen and concrete ponds is as shown in figure 2. It was observed that male fish had more percentage parasitic infestation (64.29\%) than the female fish $(57.69 \%)$ from the earthen pond while in the concrete pond, female fish had more percentage parasitic infestation $(22.73 \%)$ than the male (16.67\%).

Results of the weight distribution and parasitic infestation of Clarias gariepinus from both ponds are as shown in Table 3 and 4. It was observed that bigger fishes of weight class between 750-849g were more infested than the smaller counterpart of less than $(149 \mathrm{~g})$.

Table 1: Parasites and their location in Clarias gariepinus from earthen ponds

\begin{tabular}{ccccc}
\hline $\begin{array}{c}\text { PARASIT1C } \\
\text { SPECIES }\end{array}$ & $\begin{array}{c}\text { NUMBER OF FISH } \\
\text { INFECTED }\end{array}$ & $\begin{array}{c}\text { LOCATION OF } \\
\text { PARASITE }\end{array}$ & $\begin{array}{c}\text { PARASITE LOAD } \\
\text { ON EACH } \\
\text { LOCATION }\end{array}$ & $\begin{array}{c}\text { \% PARASITIC } \\
\text { INFESTATION ON } \\
\text { EACH LOCATION }\end{array}$ \\
\hline Eustrongylides & 12 & Stomach & 18 & 29.03 \\
Camallanus & 10 & Intestine & 10 & 16.13 \\
Hexamita species & 8 & Stomach & 10 & 16.13 \\
Hexamita species & 10 & Intestine & 12 & 19.35 \\
Tripanosoma species & 8 & Blood & 12 & 19.35 \\
\hline TOTAL & $\mathbf{4 8}$ & & $\mathbf{6 2}$ & $\mathbf{1 0 0}$ \\
\hline
\end{tabular}


Table 2: Parasites and their location in clarias gariepinus from concrete pond

\begin{tabular}{ccccc}
\hline $\begin{array}{c}\text { PARASIT1C } \\
\text { SPECIES }\end{array}$ & $\begin{array}{c}\text { NUMBER OFFISH } \\
\text { INFECTED }\end{array}$ & $\begin{array}{c}\text { LOCATION OF } \\
\text { PARASITE }\end{array}$ & $\begin{array}{c}\text { PARASITE LOAD } \\
\text { ON EACH } \\
\text { LOCATION }\end{array}$ & $\begin{array}{c}\text { \% PARASITIC } \\
\text { INFESTATION ON } \\
\text { EACH LOCATION }\end{array}$ \\
\hline Eustrongylides & 8 & Stomach & 12 & 50.00 \\
Camallanus & 2 & Intestine & 4 & 16.67 \\
Hexamita species & 4 & Stomach & 6 & 25.00 \\
Hexamita species & 2 & Intestine & 2 & 8.33 \\
Tripanosoma & 0 & Blood & 0 & 0.00 \\
species & & & $\mathbf{2 4}$ & $\mathbf{1 0 0}$ \\
\hline TOTAL & $\mathbf{1 6}$ & & & \\
\hline
\end{tabular}

$\%$ Parasitic Infestation on each location $=\frac{\text { number of parasite in per location }}{\text { Total number of parasites }} \times 100$

Table 5: Weight distribution and parasitic infestation in Clarias gariepinus from earthen pond.

\begin{tabular}{ccccc}
\hline $\begin{array}{l}\text { RANGE IN } \\
\text { WEIGHT }(\mathbf{g})\end{array}$ & $\begin{array}{c}\text { Number of fish } \\
\text { examined }\end{array}$ & $\begin{array}{c}\text { Number of fish } \\
\text { infested }\end{array}$ & $\begin{array}{c}\text { Number of } \\
\text { parasites }\end{array}$ & $\begin{array}{c}\% \text { intensity } \\
\text { of infestation }\end{array}$ \\
\hline$<149$ & 10 & 4 & $2(40.00)$ & 0.40 \\
$150-249$ & 12 & 6 & $6(50.00)$ & 0.50 \\
$250-349$ & 6 & 2 & $2(33.33)$ & 0.33 \\
$350-449$ & 10 & 6 & $6(60.00)$ & 0.60 \\
$450-549$ & 12 & 8 & $8(44.44)$ & 0.67 \\
$550-649$ & 10 & 6 & $8(80.00)$ & 0.60 \\
$650-749$ & 8 & 6 & $14(75.00)$ & 0.75 \\
$750-849$ & 12 & 10 & $16(83.33)$ & 0.83 \\
\hline
\end{tabular}

$\%$ intensity of infestation $=\frac{\text { number of fish infested }}{\text { number of fish examined }}$

Table 6: Weight distribution and parasitic infection in Clarias gariepinus from concrete pond.

\begin{tabular}{llccc}
\hline $\begin{array}{l}\text { RANGE IN } \\
\text { WEIGHT (g) }\end{array}$ & $\begin{array}{c}\text { Number of fish } \\
\text { examined }\end{array}$ & $\begin{array}{c}\text { Number of fish } \\
\text { infested }\end{array}$ & $\begin{array}{c}\text { Number of } \\
\text { parasites }\end{array}$ & $\begin{array}{c}\% \text { intensity of } \\
\text { infestation }\end{array}$ \\
\hline$<149$ & 8 & 0 & 0.00 & 0.00 \\
$150-249$ & 14 & 4 & $4(28.57)$ & 0.29 \\
$250-349$ & 4 & 0 & 0.00 & 0.00 \\
$350-449$ & 12 & 4 & $6(33.33)$ & 0.33 \\
$450-549$ & 8 & 0 & 0.00 & 0.00 \\
$550-649$ & 10 & 0 & 0.00 & 0.00 \\
$650-749$ & 10 & 2 & $8(20.00)$ & 0.20 \\
$750-849$ & 14 & 6 & $6(42.86)$ & 0.42 \\
\hline
\end{tabular}

$* \%$ intensity of infestation $=\frac{\text { number of fish infested }}{\text { number of fish examined }}$

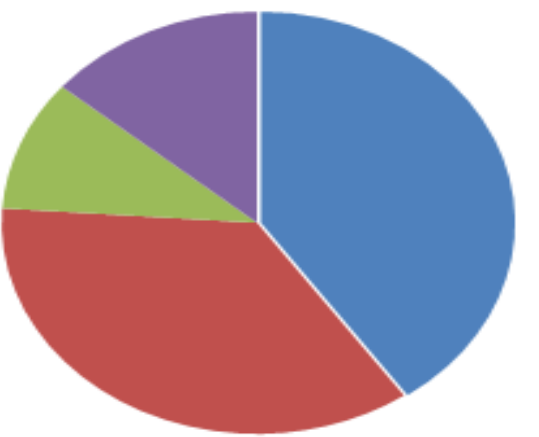

- Male from earthen pond

- Female from earthen pond

- Male from concrete pnd

- Female from concrete pond

Figure 2: Sex and percentage infestation in Clarias gariepinus from both earthen and concrete ponds.

\section{Discussion}

Results obtained from the present study shows a high infestation rate of about $77.42 \%$ and $66.67 \%$ in fish genera examined from both ponds respectively, with all recovered parasites being endoparasites; nematodes and protozoan. The high infestation rate in these fishes could be attributed to the sanitary condition of the ponds, the location of the ponds from residential areas, number and class of people visiting the ponds and their purposes. Nematodes are known to occur in body cavities or found penetrating subcutaneous tissues. Host specificity of nematodes agrees with the findings of Ekanem et al., (2011) and Akinsanya et. al., (2007). 
The higher percentage parasitic infestation $(64.29 \%)$ in male than the female $(57.69 \%)$ from earthen pond agrees with the reported work of Anosikel et al., (1992) and Oniye et al., (2004) who reported more parasitic prevalence of infestation in male fish than the female, on the other hand, the present work disagrees with the reported work of Omeji et al (20II), Emere and Egbe (2006) and Ayanda (2009), who reported higher parasitic prevalence by female in female $C$. gariepinus in their works and attributed it to the physiological state of the females, as most gravid females could have had reduced resistance to infection by parasites. In addition, their increased rate of food intake to meet their food requirements for the development of their egg might have exposed them to more contact with the parasites, which subsequently increased their chance of being infected. On the contrary, female fish from the concrete pond had more percentage parasitic infestation (22.73\%) than the male counterpart (16.67\%).

The higher number of parasites $16(83.33 \%)$ and percentage intensity of parasitic infestation $(0.83 \%)$ recorded in bigger fish with the weight class between 750-849g from earthen pond and 6(42.86\%) and $0.42 \%$ from concrete pond could be attributed to their guest for survival (Ayanda 2009). In addition, bigger fish tend to cover wider areas in search of food. As a result, they take more food than the smaller ones and these expose them more to infestation by parasites. This agrees with the reported work of Omeji et al., (2011).

\section{References}

[1] Ayanda, I.O. (2009). Comparison of parasitic helminthes infection between sexes of Clarias gariepinus from Asa dam Ilorin, northcentral Nigeria. Scientific Research and Essay. 4(4): 357-360.

[2] Akinsanya B, Otubanjo OA, Hassan AA (2007). Helminth parasites of Malapterurus electricus Malapteruridae from Lekki Lagoon, Lagos, Nig. J. Am. Sci. 3(3): 1-5.

[3] Abolarin M.O (1996). A new species of Henneguya (Myxosporida, protozoa) from West African cat fish, Clarias lazera (Val; with a review of the Genus Henneguya thelohan). The African Journal of Tropical Hydrobiology and Fisheries 1: 93 105.

[4] Anosike JC, Omoregie E, Ofojekwu PC, Nweke IE (1992). A survey of helminth parasites of Clarias gariepinus in plateau State, Nig. J. Aqua. Sci. 7: 39-43.

[5] Chandra, K.J., 2006. Fish parasitological studies in Bangladesh: a review. J. Agric. Rural. Dev. 4 (1\&2), 9-18.

[6] Doreen Z. Moyo, Chakanetsa Chimbira and Phumuzile Yalala (2009). Observations on the Helminth Parasites of Fish in Insukamini Dam, Zimbabwe. Research Journal of Agriculture and Biological Sciences, 5(5): 782-785.

[7] Dankishiya, A.S. and Zakari, M. (2007): Study on the gastrointestinal helminth parasites of Clarias gariepinus (Tuegels). In Gwagwalada, FCT, Nigeria. BEST Journal 4 (2): 79 - 81.

[8] Ekanem A. P., Eyo V. O. and Sampson A. F. (2010). Parasites of landed fish from Great Kwa River, Calabar, Cross River State, Nigeria. International Journal of Fisheries and Aquaculture Vol. 3 (12), pp. 225-230.

[9] Emere, M.C. and Egbe N.E.L (2006): Protozoan parasites of Synodontis clarias (A fresh water fish) in River Kaduna. BEST Journal 3 (3): $58-64$.

[10] Eyo A.A (1992): Utilization of freshwater fish species in Nigeria. Proceedings of the 10th annual Conference of Fisheries Society of Nigeria, Abeokuta, 16th - 20th November, $32-38$.

[11] FAO (1999): World production of fish, crustaceans and mollusks by major fishing areas. Fisheries information Data and statistic unit (FIDI), Fisheries Department, F.A.O Rome.

[12] FAO (1990); National Review for Aquaculture Development in Africa. Nigeria FAO Fisheries Circular No770.29: 19.

[13] Haruna A. B. (2006); Studies on the aspect of Socio - Economic Factors influencing fish farming in Adamawa State - Nigeria. Journal of Arid Zone Fisheries 2; 1.

[14] Ibeun, M. O. (2006): Information for Fisheries Management in Nigeria; The role of Libraries and Networking. National Institute for Freshwater Fisheries Research.

[15] Kolndadacha, O.D, Okaeme, A. N, Ibiwioye, I.I.I., Atribom, R.Y, and Musa Y.M. (2007): Fish disease control: A key success to aquaculture development in Nigeria. National Institute for freshwater fisheries Research, New - Bussa, Niger State. Nigeria. BEST Journal 4 (1): 84-90.

[16] Kori-Siakpere Ovie , Adamu Kabir , O (2005) Sublethal Effects of Paraquat on Some Plasma Organic Constituents (Metabolic Parameters) of African Catfish: Clarias gariepinus (Osteichthys-Clariidae) Pp 23. Khalil L.F and Polling K (1997). Checklist of the African Freshwater Fishes. University of the North Department of Zoology. Republic of South Africa, p. 189.

[17] Martinez-Aquino A. and Aguillar-Aguillar R. (2008) Helminth parasites of the pupfish Cyprinodon meeki (Pisces: Cyprinodontiformes), an endemic freshwater fish from North Central Mexico. Helminthologia, 45(1): 48-51.

[18] Martinez-Aquino A., Salgado-Maldonado G., Angullar R., Cabanas-Carranza G. and Ortega-Olivares M.P. (2004) Helminth parasites of Chapalichthys encaustus (Pisces: Goodeidae), an endemic freshwater fish from lake chapala, Jalisco, Mexico. Journal of Parasitology, 90(4): 889-890.

[19] Mashego, S.N., (2001): Redistribution of Proteocephalus glanduligar. Annals of the Transvaal museum $38: 13$ - 17.

[20] Omeji, S., S.G. Solomon and E.S. Idoga (2011): A Comparative Study of the Common Protozoan Parasites of Clarias gariepinus from the wild and cultured environments in Benue State, Nigeria. Journal of Parasitology Research. $2011: 8$.

[21] Onyedineke NE, Obi U, Ofoegbu PU, Ukogo I (2010). Helminth Parasites of some Freshwater Fish from River Niger at Illushi, Edo State, Nig. J. Am. Sci., 6(3): 16-21.

[22] Oniye, S.J., Adebote, D.A., and Ayanda O.I., (2004): Helminthes parasites of Clarias gariepinus (Tuegels) in Zaria. Nig. Journal of Aquatic Sci. 19(2):71 -5.

[23] Paperna I. (1991) Diseases caused by parasites in the aquaculture of warm water fish. Annual Review of Fish Diseases 1: $155-194$

[24] Roberts, L.S., and Janovy, J., (2000). Foundation of Parasitology. 6th Ed McGraw - Hill International Edition, Boston. Pp 105-113

[25] Southeast Asian Fisheries Development centre (SEAFDEC) (1999): The AFS-FHS Fourth Symposium on Diseases in Asian Aquaculture. SEAFDEC, Asian Aquaculture. XX1 (6):6-10

[26] Shukerova S., Kirin D. and Hanzelova V. (2010) Endohelminth communities of the perch, Perca fluviatilis (Perciformes, Percidae) from Srebama Biosphere Reserve, Bulgaria. Helminthologia, 47(2): 99-104.

[27] Willoughby, N. G. (1974). The ecology of Synodontis (Pisces: Siluroides) in Lake Kainji, Niger, Nigeria. Ph. D. thesis, University of Southampton. 288 p. 